\title{
The impact of trade openness on regional inequality : the cases of India and Brazil
}

Marie DAUMAL 


\title{
THE IMPACT OF TRADE OPENNESS ON REGIONAL INEQUALITY : THE CASES OF INDIA AND BRAZIL ${ }^{1}$
}

\author{
Marie Daumal \\ Université Paris 8 Vincennes-Saint-Denis \\ Université Paris-Dauphine, LEDa, UMR DIAL \\ marie.daumal@univ-paris8.fr \\ Document de travail UMR DIAL \\ Février 2010
}

\begin{abstract}
Regional inequalities are large in India and Brazil and represent a development challenge. This paper aims to determine whether regional disparities are linked to countries' trade openness. An annual indicator of regional inequalities is constructed for India over the period 1980-2003 and for Brazil over 1985-2003. Results from time series regressions show that Brazil's trade openness contributes to the reduction in regional inequalities in Brazil. The opposite result is found for India. India's trade openness is an important factor aggravating income inequality among Indian states. In both countries, the inflows of foreign direct investment are found to increase regional disparities.
\end{abstract}

Key words : Trade openness, regional inequality, India, Brazil, time series regression.

\section{Résumé}

Dans les années 90, les inégalités régionales ont fortement augment'e en Inde. Les inégalités entre Etats brésiliens sont importantes et constituent un problème politique majeur pour la fédération brésilienne. En 1991, ces deux pays se sont progressivement ouverts au commerce international. L'objectif du papier est de déterminer s'il existe ou non un lien entre les inégalités régionales et l'ouverture commerciale dans les cas de l'Inde et du Brésil. J'ai construit un indicateur, l'index Gini, qui est une mesure des inégalités régionales, sur la période 1980-2004 pour l’Inde et sur la période 1985-2004 pour le Brésil. Cet indicateur des inégalités régionales est ensuite régressé sur divers déterminants dont l'ouverture commerciale des pays, en utilisant la technique des séries temporelles et des modèles vectoriels à correction d'erreur. Je trouve que l'ouverture commerciale de l'Inde a fortement aggravé les inégalités existant entre l'Inde du Nord, de plus en plus pauvre, et l'Inde du Sud de plus en plus riche. Or ces inégalités régionales croissantes sont maintenant une source de tension et de conflits au sein de la fédération indienne, les Etats du Sud ne voulant plus "payer" pour le Nord du pays. Au contraire, l’ouverture du Brésil semble avoir entraîné une diminution des inégalités entre Etats brésiliens.

Mots clés : Ouverture commerciale, inégalités régionales, Inde, Brésil, séries temporelles.

JEL Classification : F43, R11 


\section{Introduction}

Regional inequalities, namely per capita income inequalities across states, are a matter of serious concern in India and in Brazil. Regional disparity has been rising in India since the 1990s and now reachs a critical level. Currently, one of the major concerns of the Indian central government is that the rising regional disparities might affect India's political unity. Regional disparities have always been large in Brazil. On his election in 2002, President Lula da Silva stated that efforts to combat regional inequalities would be one of his priorities. There is a growing consensus among the Brazilian political parties that addressing regional inequalities that expose the country to the risk of fragmentation is a major challenge and a priority for Brazil. Both countries have undergone trade liberalization in the 1990's. India's liberalization program of 1991 reduced trade barriers. Before 1987, Brazil was one of the most heavily protected economies in the world. Trade liberalization mainly occured between 1988 and 1995. A strategy of outward orientation led to reductions in tariffs and removal of other trade barriers. An important question for a country is to know whether the country's insertion into the global economy will affect the regions' economic development and thus impact on regional inequality. Focusing on trade globalization, this paper aims to determine whether or not the evolution of regional inequality in India and Brazil is linked to their trade openness.

The new economic geography models have explored the effects of trade openness on regional disparities. Krugman and Livas Elizondo (1996) show that trade liberalization reduce spatial disparities across regions. In their model, when a country opens to international trade, firms relocate in periphery to avoid congestion costs. Paluzie (2001) finds that regional inequality rises as international trade in manufacturing increases. The model shows that firms agglomerate after trade liberalization in the central region to benefit the various advantages of agglomeration. Crozet and Koenig-Soubeyran's (2004) model shows that the impact of trade liberalization on spatial disparities depends on the specific internal geography of the country. When one of the regions of the country has a better and lowest-access to foreign markets, trade liberalization fosters a cumulative agglomeration process in this advantaged region. The new economic geography models differ concerning their predictions - trade openness is likely to reduce or aggravate regional inequalities - that are dependent on the type of agglomeration and dispersion forces included resulting from the chosen hypotheses. Theory does not allow to predict the impact of greater trade openness on regional inequality. That is why empirical studies are important.

Empirical studies on trade openness and regional inequality are only case studies of a few countries and, as the economic geography models, they lead to contradictory results. Gonzales Rivas (2007) finds that trade liberalization increases regional disparities in Mexico whereas Paluzie, Pons and Tirado (2004) show that industrial concentration and regional inequality have decreased in Spain since 1960 and the European integration. Ge (2006) shows that foreign trade and inflows of foreign direct investment (FDI) are positively correlated to industry agglomeration in China in the coastal regions. Using panel data analysis, Milanovic (2005) finds that trade openness results in more regional inequality in India, Brazil, Indonesia, China and the United States. 
Many studies (Sachs, Bajpai and Ramiah, 2002, for instance) have investigated regional disparities in India but very few studied the link between India's trade openness and inequality among Indian states. Barua and Chakraborty (2006) finds that trade openness reduces regional inequality in India. Aghion, Burgess and Redding (2004) show that India's 1991 trade liberalization fosters growth only in the most productive Indian industries located in already-advantaged states (Karnataka, Andra Pradesh, Tamil Nadu), thereby tending to increase regional inequalities. Regional disparities in Brazil have been studied by Horridge and de Souza (2004), for instance. The authors use a general equilibrium model to examine how trade openness affects poverty in Brazilian states. They find no evidence for a trade effect on poverty in states.

Given the outcomes from theory and empirical studies on the link between regional inequality and trade openness, it seems that trade openness may have a different effect on regional disparities depending on the country. A case study of a national experience such as the Indian and Brazilian experiences can offer a useful complement to the literature. This study uses the time series analysis to investigate the effects of trade openness on regional inequalities. First, an annual indicator of regional inequalities is constructed for India between 1980 and 2004 and for Brazil between 1985 and 2004. This calculation allows to know the evolution of regional inequalities in both countries. Secondly, this indicator that is a proxy of regional inequalities is regressed in time series regressions, for each country, on country's trade openness and other determinants of regional inequalities such as the inflows of FDI.

The main empirical results are : (i) in Brazil, trade openness contributes to the decline in regional disparities and (ii) in India, more trade openness means more regional inequalities. Then possible explanations for these findings are explored such as the composition of foreign trade. A result is that a shift from exports in agriculture to exports in manufacturing products could partly explain the rise of inequality among Indian states. The contribution to the literature is thus to provide consistent estimations of the impact of trade openness on regional inequalities in India and Brazil and to provide possible explanations for these findings.

The paper is organized as follows. Section 2 describes the calculation of the indicator of regional inequality and provides some stylized facts on regional inequality in Brazil and India. Section 3 presents the econometric methodology used to estimate the impact of trade on regional disparities. Section 4 presents the results obtained for Brazil and India and explores some possible explanations. Section 5 discusses the results. Section 6 concludes.

\section{Constructing an indicator of regional inequality in Bra- zil and India}

\subsection{Calculating the Gini index of regional inequality}

An annual indicator of regional inequality for Brazil and India is calculated over the periods 1985-2004 and 1980-2004 respectively. Gini index is widely used in the inequality literature to measure the extent to which the distribution of income among individuals deviates from a per- 
fectly equal distribution. Gini coefficient varies between 0 (complete equality) and 1 (complete inequality). There are not many available data on regional inequality. Due to this lack of data, empirical analyses on openness and regional inequality, based on cross-countries regressions, do no exist. Thus an indicator of regional inequality must be constructed for this study. As Gini index is widely used in the inequality literature, it is used here as a measure of the level of inequalities among states. In its calculation, states are considered as individuals.

Gini index is calculated as shown in Eq. (1) and measures the income per capita inequality across 19 Indian states, considered as individuals, for each year between 1980 and 2004 and across 26 Brazilian states for each year between 1985 and 2004. More precisely, Eq. (1) is the formula of the weighted Gini index that weights the states' per capita GDP based on their respective population proportions. Weighting by population involves that states does not count the same. That is, the more populated an Indian state is, the more the gap between its income and the average income will be taken into account to calculate the Gini index. Per capita incomes data and population data by state and by year are necessary to construct the Gini coefficient. Per capita incomes data are not available before 1980 for India and not available for Brazil before 1985 and are not available either for both countries for 2005 and 2006. Thus, the periods studied in this paper are due to the availability of per capita incomes data at a subnational level.

The weighted Gini index is computed using the usual formula of Gini coefficient :

$$
G i n i=\frac{1}{G D P m} \sum_{i}^{n} \sum_{j>i}^{n}\left(G D P_{j}-G D P_{i}\right) \operatorname{Pop}_{i} \operatorname{Pop}_{j}
$$

where $\mathrm{n}$ is the number of Indian states if Gini is calculated for India; $\mathrm{i}$ and $\mathrm{j}$ an Indian state; $G D P_{m}$ is the mean of GDP per capita of the 19 Indian states weighted by states' populations; $G D P_{i}$ is GDP per capita of the i-th Indian state; states' GDP data are provided in current local currency. Data sources are detailed in the Appendix A. Pop $p_{i}$ is the population share of the i-th state in the total Indian population. The Gini coefficient is calculated from 19 Indian states out of 28 states that are the largest states comprising 98.2 percent of total Indian population in 2003. The same calculation is repeated for Brazil and the 26 Brazilian states. Calculated Gini coefficients are reported in Table 1.

\subsection{Stylized facts on regional inequality in Brazil and India}

Figure 1 reports the Gini index of inter-state disparities in India and India's trade openness from 1980 to 2004. Trade openness is the sum of exports and imports in percentage of GDP in a given year t. Data come from World Bank's World Development Indicator (WDI). In the eighties, trade openness and regional inequality are rather stable. Then, there is a dramatic increase in regional disparities in 1991 post liberalization period : regional inequality and trade openness were rising altogether in India during the last fifteen years. The correlation coefficient between the Gini index and trade openness is equal to 0.96. The year 2004 indicates an unusually rise 
TAB. 1 - Gini index as indicator of the level of regional inequality in India and in Brazil

\begin{tabular}{l|rrrrrrrrrrrr}
\hline & 1980 & 1981 & 1982 & 1983 & 1984 & 1985 & 1986 & 1987 & 1988 & 1989 & 1990 & 1991 \\
\hline India & .160 & .172 & .163 & .164 & .164 & .165 & .164 & .171 & .167 & .183 & .177 & .185 \\
Brazil & & & & & & .273 & .263 & .283 & .289 & .290 & .278 & .270 \\
& & & & & & & & & & & & \\
& & & & & & & & & & & & \\
\hline & 1992 & 1993 & 1994 & 1995 & 1996 & 1997 & 1998 & 1999 & 2000 & 2001 & 2002 & 2003 \\
\hline India & .207 & .217 & .222 & .235 & .230 & .234 & .233 & .238 & .241 & .247 & .255 & .256 \\
Brazil & .275 & .267 & .257 & .269 & .261 & .267 & .269 & .263 & .261 & .258 & .248 & .238 \\
\hline
\end{tabular}

Note : The higher the Gini index, the higher the regional inequality

Source : calculation of the author

in India's trade openness ratio that increases from $31 \%$ to $40 \%$. This unusual increase will be treated as an outlier data. In consequence, this paper studies the impact of trade openness over this period 1980-2003. In a country of India's size, significant regional inequality is not a surprise. However, the evolution of these regional inequalities is of concern. In Table 5 in the Appendix which reports per capita GDP of Indian states in 1980 and 2000, it can be observed that the hierarchy of the richer Indian states remained quite the same over the period. The richer states in 1980 are the same ones as in 2000. Geographically (see Figure 2 in the Appendix), the forward group of states (Maharashtra, Goa, Karnataka) fall in the southern parts of the country and are contiguous, excepted for the region of the capital New Dehli and Punjab.

Evolution of inter-state inequality in Brazil differ from the Indian experience. Figure 1 also reports the Gini index of inter-state disparities in Brazil and Brazil's trade openness from 1985 to 2004. Regional inequality and trade openness in Brazil varied over the period 1985-2004 with alternating periods of increase and decrease. There is no noticeable trend between 1985 and 1998. Then, there has been an increase in trade openness and a decline in regional inequality since 1998. The correlation coefficient between Gini index and trade openness is -0.75. In Brazil, the north and north-east regions are the poorest (see Figure 3 in the Appendix). Per capita GDP of the southeast region is more than three times that of the north.

In conclusion, the country experiences differ and the rough data show that : (i) In India, trade openness might be associated with increasing regional inequalities ; (ii) In Brazil, trade openness seems to be associated with a decline in regional inequality. However, concomitance of greater trade openness and rising (or decreasing) regional disparities does not mean causation and it has still to be demonstrated that trade openness impacts on regional disparities in both countries.

\section{Methodology}

The empirical methodology consists in regressing in a time series equation the Gini index of regional inequality on various determinants and on the country's trade openness. The next subsection identifies the determinants of regional inequality to be taken into account and the subsection 3.2 presents the empirical equation used to estimate the impact of trade openness 
FIG. 1 - Trade openness and regional inequality in India (1980-2004) and in Brazil (1985-2004) Note : Gini index is the calculation of the author (see Table 1), the higher the index, the higher the regional inequalities. The trade openness ratio is the sum of exports and imports in percentage of GDP.
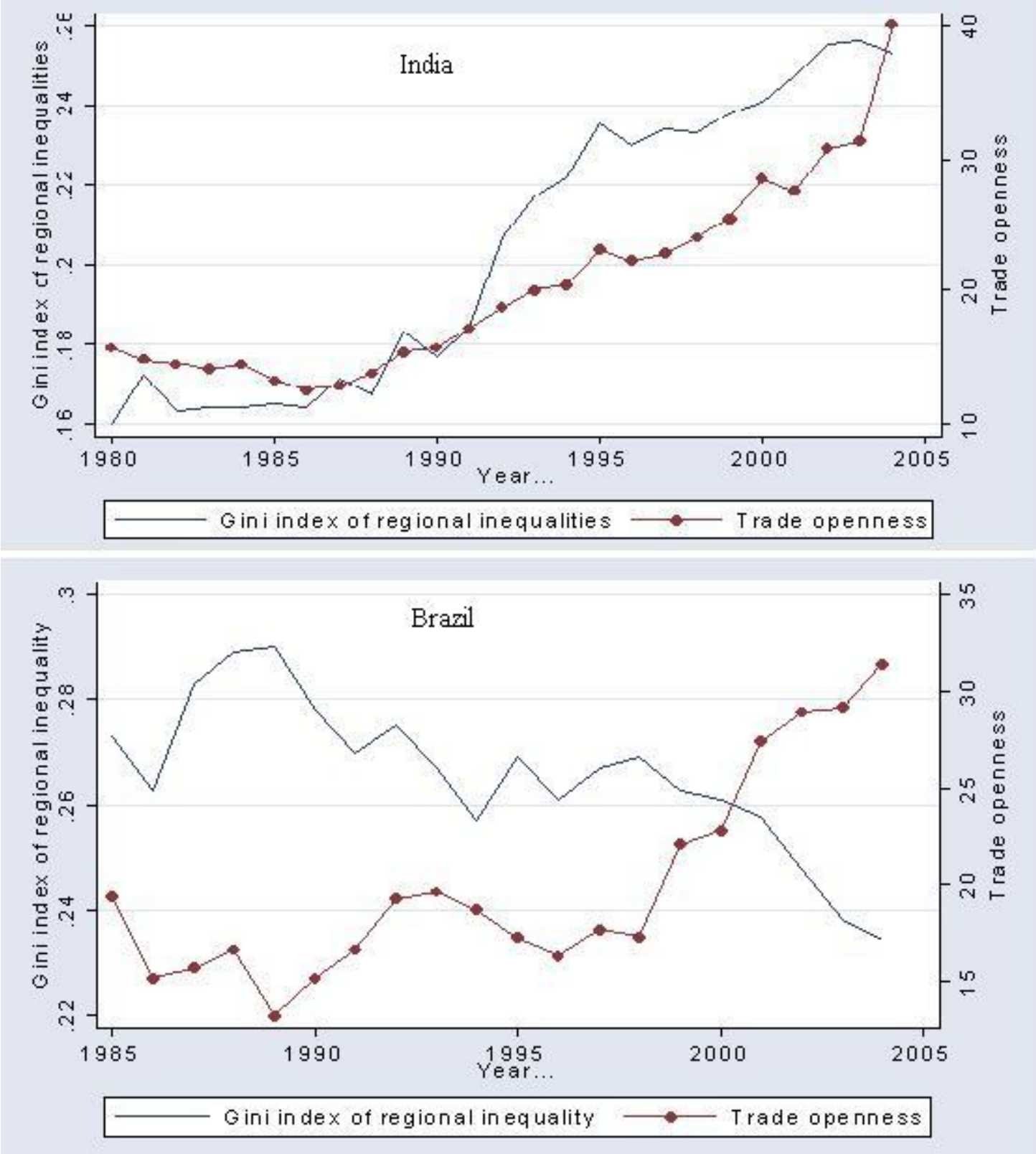
on regional disparities.

\subsection{The determinants of regional inequality}

Some of the factors of the level of regional disparities are intrinsic to the country and depend on countries' specificities. They are, for instance, the history of the national economic development, the geographic advantages of some regions and the climate. Fiess and Verner (2003) explain that the inequality between the northeast and the south of Brazil goes back centuries. The scope of this paper is not to explain the level of regional inequalities in India and in Brazil but their evolution over time in the last twenty years. Wei and Wu (2001) argue that studying inequality in a short time period has one advantage. Any inequality within a country depends on history, culture, legal system and other national institutions. Over a short time period, these factors of inequality can be considered as constant and the researcher is more able to isolate the influence of current phenomena such as trade openness.

New economic geography models predict that trade openness has an impact on regional inequality. Then, this prediction is tested empirically by specifying an empirical equation where regional inequalities are regressed on trade openness. The exclusion of relevant factors of inequality potentially correlated with trade openness may result in a biased estimation of the impact of trade openness variable on inequality. The control for factors that may drive both trade openness and regional inequality is thus necessary. Other factors of regional inequality can be omitted from the empirical equation provided they are not correlated with trade openness. Their effect will be included in the error term and their omission will not introduce substantial bias in the estimates of coefficients on the trade openness variables.

Foreign direct investment inflows could be a factor of regional inequality in India and in Brazil and be correlated with their trade liberalization. FDI are concentrated in both countries in the most developed states. Hansen and Rand (2006) show that FDI convey advantages to host countries and that they have a positive effect on growth. FDI is also seen as a vehicle for technological spillover. By promoting the growth of richer states, the concentration of FDI in richer Indian and Brazilian states probably aggravates the economic gap between rich and poor states. Thus, inflows of FDI are included as a determinant of regional regionalities and are expected to exarcerbate them.

Per capita income of the country is also included in the empirical equation as determinant of regional inequality. Indeed, literature has expressed the idea of a non-linear relationship between economic development and regional inequalities. Indeed, Williamson (1965) or Lucas (2000) argue that regional inequalities follow an inverted U-shaped curve depending on the country's level of development. Regional inequality should first rise then diminish. At the early stages of the development process, growth is expected to be spatially unbalanced. According to Milanovic (2005), the impact of economic development on regional inequality depends on what drives growth. When growth is fuelled by agricultural growth, growth can foster convergence and reduce regional inequality. When growth is fuelled by industrial growth and that industries are subject to agglomerative forces, growth can create regional inequalities. As regards Brazil, 
Azzoni (2001) finds that fast growth periods are associated with a rise in regional inequalities in Brazil between 1939 and 1995.

\subsection{The empirical equation}

To investigate the impact of trade openness on regional inequalities in India and in Brazil, the time series equation of the following form is specified :

$$
\operatorname{lnGini} i_{t}=a_{0}+a_{1} \operatorname{lnOpenness_{t}}+a_{2} \operatorname{lnFDI_{t}}+a_{3} \ln G D P \text { capita } a_{t}+u_{t}
$$

The dependent variable is the Gini $_{t}$ index that is the measure of regional inequality for the year t presented in Table 1. The variable Openness is $_{\text {is }}$ the measure of India's or Brazil's trade openness. This is the sum of exports and imports in percentage of GDP in a given year t, which is a common measure of trade openness. The trade openness ratio is presented in Figure 1. The variable $F D I_{t}$ is the net inflows of FDI in percentage of the GDP in India or in Brazil. Data on FDI are presented in Table 3. The variable GDPcapita is India's or Brazil's per capita GDP in constant 2000 US dollars and is a control variable for the level of development. For all equations in this paper, $t$ denotes the year $\mathrm{t}$ and $l n$ is the log. All data sources are presented in the Appendix A. Eq. (2) is estimated from 1980 to 2003 for India and from 1985 to 2004 for Brazil due to availability of the data.

This paper uses the unit root tests, the cointegration techniques and the error-correction models to test the causal relationship between trade openness and regional disparities. Direct OLS estimations of Eq.(2) are not appropriate if time series are not stationary. Indeed, there is a risk of spurious regression when the variables are non-stationary. The econometric methodology is presented in details in the Appendix B.

\section{Empirical results}

\subsection{Results from the error correction model estimations}

First, estimation for Brazil is conducted. Considering Eq. (2), the unit root and time series properties of all series $\left(\operatorname{lnGini}_{t}, \operatorname{lnOpennes}_{t}, \ln F D I_{t}\right.$ and $\ln G D P$ capita $\left._{t}\right)$ are investigated using the Augmented Dickey-Fuller and Phillips-Perron unit root tests. For space reason, the test statistics are not reported in this paper but are available upon request. The unit root test results indicate that the time series $\operatorname{lnGini}_{t}$, lnOpenness $s_{t}$ and $\ln G D$ Pcapita $_{t}$ are I(1), integrated of order one. The serie $\ln F D I_{t}$ is a TS, that is with a time trend. Having confirmed the existence of unit root for three time series, the next step involves conducting Engle-Granger two-step cointegration method. The aim is to determine whether the series InOpenness and lnGDPcapita are cointegrated with $\ln G i n i$. Results from the Engle-Granger method show that the variables

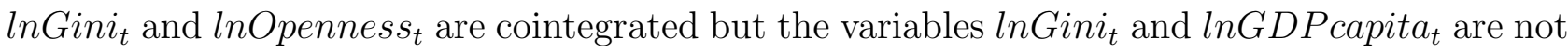
cointegrated. 
Since the variables $\ln$ Gini and lnOpenness are cointegrated in Granger sense, the use of error correction model (ECM) procedure is appropriate. If two variables are cointegrated, then the relationship between the two can be expressed as ECM of the following form :

$$
\text { D.lnGini }{ }_{t}=a_{0}+a_{1} \text { residual }_{t-1}+a_{2} \text { D.lnOpenness }{ }_{t}+X_{t}^{\prime} \beta+u_{t}
$$

D. denotes $\mathrm{I}(1)$ variables stationarized in first-difference. D. is the differencing operator such that D.lnGini $i_{t}$ is equal to $\ln G i n i_{t}-{\ln G i n i_{t-1} \text {. The variable residual }}_{t-1}$ is the serie of the lagged residuals collected from the regression of the variable $\ln G i n i_{t}$ on the explanatory variable lnOpenness $s_{t} X_{t}^{\prime}$ are any exogenous stationnary variables, which are here the GDP per capita and the inflows of FDI both stationarized. The variable $\ln F D I_{t}$ is stationarized by removing the trend. The ECM of Eq.(3) says that changes in trade openness, in inflows of FDI and in per capita GDP cause regional inequality to change. The estimation of Eq.(3) is presented in column 2 of Table 2. Column 1 reports the long-run relationships between lnGini and lnOpenness.

In column 2 of Table 2 , the trade openness variable D.lnOpenness $s_{t}$ yields a negative (-0.11) and significant coefficient : the opening of the national economy to the foreign market appears to have reduced regional inequality in Brazil. Milanovic (2005) finds the opposite result for Brazil since his regression analysis using panel data including India, Brazil, the USA, Indonesia and China establishs that trade openness results in greater regional inequality. Yet, Milanovic (2005) and this paper regress the same weighted Gini index of regional inequality. But, while Eq. (2) is a time series regression for Brazil, Milanovic (2005) uses panel data regressions including five countries. Besides, the non-stationnarity of the data is not handled, which could explain the difference in outcomes. Concerning the other factors of regional inequalities, in Milanovic (2005), the weighted Gini index is regressed on trade openness as well, on GDP per capita, on interest rate and inflation rate but FDI are not included. In the absence of FDI as an explanatory variable, trade openness could capture the positive impact of FDI on inequality. In column 2 of Table 2, the coefficient of the lagged residual term included in the ECM is significant and negative equal to -0.69 , which is expected if there exists a cointegration relationship between the variables $\ln$ Gini and lnOpenness.

The same econometric methodology is used for India. The series $\ln G i n i_{t}, \ln$ ppenness $_{t}, \ln F D I_{t}$ and $\operatorname{lnGDPcapita} a_{t}$ are found to be integrated of order 1 and the series lnOpenness and $\operatorname{lnFDI}$ are cointegrated with $\ln$ Gini. If trade openness and the inflows of FDI are cointegrated with the Gini variable, then the relationship between the three can be expressed as ECM of the following form :

$$
D . \ln \text { ini }_{t}=a_{0}+a_{1} \text { residual }_{t-1}+a_{2} \text { D.lnOpenness }{ }_{t}+a_{3} D . \ln F D I_{t}+a_{4} D \cdot \ln G D \text { Pcapita }_{t}+u_{t}
$$

The variable residual $_{t-1}$ is the serie of the lagged residuals collected from the regression of the variable $\ln _{n}$ ini $_{t}$ on the cointegrated variables $\ln$ Openness $_{t}$ and $\ln F D I_{t}$. The estimation of Eq. (4) is presented in column 4 of Table 2. Column 3 reports the long-run relationships between the cointegrated $\ln$ Gini, InOpenness and $\ln F D I$. The coefficient on the trade openness 
TAB. 2 - Estimation of the error correction models. Estimation of the impact of trade openness on regional inequality. Brazil, 1985-2004, and India, 1980-2003.

\begin{tabular}{|c|c|c|c|c|}
\hline & \multicolumn{4}{|c|}{ Dependent variable : Regional inequality (Gini index) } \\
\hline & \multicolumn{2}{|c|}{ Brazil } & \multicolumn{2}{|c|}{ India } \\
\hline & $\begin{array}{c}\ln \operatorname{lini}_{t} \\
\quad(1)\end{array}$ & $\begin{array}{c}D . \ln \text { Gini }_{t} \\
(2)\end{array}$ & $\begin{array}{c}\ln \operatorname{lini}_{t} \\
(3)\end{array}$ & $\begin{array}{c}D . \ln G i n i_{t} \\
(4)\end{array}$ \\
\hline lnOpenness ${ }_{t}$ & $\begin{array}{c}-.19 \\
(.029)^{* * *}\end{array}$ & & $\begin{array}{c}.40 \\
(.041)^{* * *}\end{array}$ & \\
\hline $\ln F D I_{t}$ & & & $\begin{array}{c}.04 \\
(.009)^{* * *}\end{array}$ & \\
\hline $\begin{array}{l}\text { D.lnOpenness } \\
\text { (export + import to GDP) }\end{array}$ & & $\begin{array}{l}-.11 \\
(.064)^{*}\end{array}$ & & $\begin{array}{c}.40 \\
(.094)^{* * *}\end{array}$ \\
\hline D.lnGDPcapitat & & $\begin{array}{l}-.22 \\
(.273)\end{array}$ & & $\begin{array}{l}.24 \\
(.310)\end{array}$ \\
\hline $\begin{array}{l}\ln F D I_{t s} \text { or } D \cdot \ln F D I_{t}{ }^{*} \\
\text { (inflows of FDI) }\end{array}$ & & $\begin{array}{c}.02 \\
(.010)^{*}\end{array}$ & & $\begin{array}{c}.03 \\
(.010)^{* * *}\end{array}$ \\
\hline residual $_{t-1}$ & & $\begin{array}{c}-.69 \\
(.215)^{* * *}\end{array}$ & & $\begin{array}{l}-.71 \\
(.137)^{* * *}\end{array}$ \\
\hline constant & $\begin{array}{l}-.76 \\
(.087)^{* * *}\end{array}$ & $\begin{array}{l}-.00 \\
(.007)\end{array}$ & $\begin{array}{l}-2.74 \\
(.137)^{* * *}\end{array}$ & $\begin{array}{l}-.00 \\
(.015)\end{array}$ \\
\hline $\begin{array}{l}\text { observations } \\
R^{2}\end{array}$ & $\begin{array}{c}20 \\
0.70\end{array}$ & $\begin{array}{c}19 \\
0.53\end{array}$ & $\begin{array}{c}24 \\
0.96\end{array}$ & $\begin{array}{c}23 \\
0.59\end{array}$ \\
\hline
\end{tabular}

Note : Robust standard errors in parentheses; ${ }^{* * *},{ }^{* *}$ and ${ }^{*}$ represent respectively statistical significance at the $1 \%, 5 \%$ and $10 \%$ levels. ${ }^{*}$ The serie is stationarized in first-difference for India and by removing the trend for Brazil.

variable D.lnOpenness $s_{t}$ is positive $(+0.40)$ and highly significant : the opening of the national economy to the foreign market appears to have aggravated regional inequality in India. This result is similar to that found by Milanovic (2005) who finds that greater trade openness results in more regional inequality in India. However, it is the opposite of that found by Barua and Chakraborty (2006) who find that trade openness reduced regional inequality in India over the same period. Their econometric estimation consists in regressing a Theil index of regional inequality on a trade openness variable using time series. But control variables are not included in their empirical estimation and the stationarity of the variables is not tested, which could explain the difference in outcomes.

As said in the introduction, new economic geography models differ concerning their predictions on the impact of trade on regional inequalities. The empirical results illustrate well this indecisiveness since Brazil's trade openness is found to contribute to a reduction of inequality among Brazilian states whereas India's trade openness is found to contribute to a rise of regional inequality. 
The results for the other determinants of regional inequalities are now commented. In the estimations of the ECM in columns 2 and 4 of Table 2, the coefficients on the FDI variables are significant and positive, equal to +0.02 and to +0.03 , which indicates that FDI reinforce regional inequality in India and Brazil. This result was expected. Since the opening of its economy in the nineties, Brazil has experienced a great increase in inflows of FDI, most of which has been concentrated in richer regions such as São Paulo or Rio Grande do Sul. Indeed there is clearly a leadership of the southeast region in attracting foreign investment. According to Bacen (Foreign Capital Census of the Brazilian Central Bank), the southeast concentrated $91 \%$ of all assets of firms with foreign control in 1995. FDI probably favor the growth rate of the host rich states and provides additional advantages to the already well-developed states, thereby tending to increase regional inequality. FDI were also expected to reinforce inequalities among Indian states. Indeed, since the liberalization of 1991, India has also experienced a continous increase in inflows of FDI, most of which has been concentrated in richer states. According to FDI data of the Indian Ministry of Commerce, the top five states that receive high levels of FDI between 1991 and 2002 are the richest states (Maharashtra, Tamil Nadu, Karnataka, Gujarat) and the capital, Dehli. In terms of the destination of FDI flows in 2003, New Dehli (26\% of the total FDI inflows) and Maharashtra (25\%) top the list followed by Karnataka (10\%), Tamil Nadu (6\%) and Gujarat (4\%). FDI probably favor the growth rate of the host rich states, thereby tending to increase regional inequality. Nunnenkamp and Stracke (2007) who study the determinants of FDI location and their growth effects in India also find that FDI is likely to increase India's regional inequality because FDI are concentrated in already advanced regions and highly foster their economic growth. Ge (2006) finds a same result for China showing that FDI reinforce industry agglomeration in China, especially in the coastal Chinese regions that have the best access to foreign markets.

As regards Brazil and India, in columns 2 and 4 respectively, the coefficients on the variables D.lnGDPcapita are not significant, which indicates that there is not an instantaneous causality from economic development to regional inequality in both countries.

TAB. 3 - Net infows of FDI in percentage of countries' GDP in India and Brazil. Selected years over the period 1980-2003.

\begin{tabular}{l|cccccccccc}
\hline & 1980 & 1983 & 1985 & 1987 & 1990 & 1993 & 1995 & 1997 & 2000 & 2003 \\
\hline & & & & & & & & & & \\
India & 0.04 & 0.003 & 0.05 & 0.08 & 0.08 & 0.20 & 0.60 & 0.87 & 0.78 & 0.76 \\
Brazil & \multicolumn{1}{c}{0.65} & 0.40 & 0.21 & 0.29 & 0.69 & 2.43 & 5.45 & 2.01 \\
\hline
\end{tabular}




\subsection{Robustness checks}

\subsubsection{Estimating vector error correction models}

The aim is to check the robustness of the results on the trade openness variable, which is the main interest of the paper. A way to test the robustness is to estimate an vector autoregression (VAR) model or a vector error correction model (VECM) (see Appendix B for more details). The VAR suggests that the current (time t) observation of regional inequality depends on its own lags as well as on the lags of each other variable in the equation (trade openness, inflows of FDI and GDP per capita). All variables are included in the VAR equation after being stationarized. For both countries, the optimal lag lenght is 2 according to the AIC criterion. The cointegration between variables is taken into account through including an error term as in the ECM. The VECM can be expressed of the following form for Brazil :

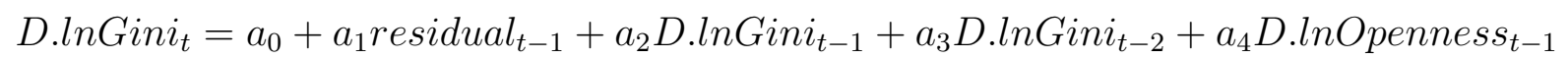

$$
\begin{aligned}
& +a_{5} \text { D.lnOpenness } \text { t-2 }+a_{6} \ln F D I_{t-1}+a_{7} \ln F D I_{t-2} \\
& +a_{8} D \cdot \ln G D \text { Pcapita } a_{t-1}+a_{9} D \cdot \ln \text { GDPcapita } a_{t-2}+u_{t}
\end{aligned}
$$

Estimations of the VECM models are reported in Table 6. Columns 1 and 2 reports the estimations for Brazil and columns 3 and 4 for India. In column 1, Eq. (5) is estimated. The coefficients on the lagged values of trade openness are significant and negative $(-0.16$ and -0.15$)$. This means that lagged values of Brazil's trade openness are useful in forecasting regional inequality in Brazil : more trade openness means less regional inequality in future, which confirms the results from the ECM estimation in previous subsection. It is possible to provide a concrete interpretation of this result. The coefficient on the openness variable is equal to -0.16. Assuming that Gini index in Brazil is equal to 0.26 at year 2000, if Brazil's trade openness increased from $20 \%$ of GDP to $25 \%$ of GDP from year 1999 to year 2000, Gini index should decrease from 0.26 in 2000 to 0.249 in 2001, which is rather important. An increase in trade openness reduces the Gini index of regional inequalities. In column 2 of Table 6 , the dependent variable is now Brazil's trade openness. The lagged values of D.lnGini (regional inequality) and the error correction term are not significant, which indicates that regional inequality in Brazil do not Granger-cause Brazil's trade openness. That is, there is probably one-way causality from trade openness to regional inequality but not the reverse. Trade openness does not seem to be endogenous to regional inequality.

Column 3 of Table 6 reports the estimation for India. The regional inequality is the dependent variable. The coefficients on the lagged values of trade openness are significant and positive $(+0.49$ and +0.33$)$, which confirms the results from the ECM regression. Lagged values of India's trade openness are useful in forecasting income disparities among Indian states : more trade openness means more regional disparities in future. Let's take the coefficient of +0.49 on the lagged value of trade openness. Assuming Gini index in India is equal to 0.20 at year 1992, if India's trade openness increased from $20 \%$ of GDP to $25 \%$ of GDP from year 1991 
to year 1992, Gini index should increase from 0.20 in 1992 to 0.222 in 1993, which is quite important. A rise of trade openness increases Gini index of regional inequalities. In column 4 of Table 6 , trade openness is now the dependent variable. The lagged values of D.lnGini and the error correction term are not significant : inequality among Indian states does not seem to Granger-cause India's trade openness. There is one-way causality from trade openness to regional inequality in India but the reverse is not true. In conclusion, the VECM estimations confirm the results from the ECM estimations. Trade openness reduces regional inequality in Brazil and aggravates regional inequality in India.

\subsubsection{The role of decentralization in regional disparities in India}

The preceding analysis assumes that the evolution of regional disparities is influenced by trade openness, inflows of FDI and national economic development. But another possible determinant of regional inequalities is fiscal decentralization. Rodriguez-Pose and Gill (2003) show that rising regional disparities and decentralization have become established trends since the eighties in China, India, Mexico, Spain, and the US. In the nineties, India favored a greater redistribution of authority to the sub-national levels. According to the authors, decentralization of expenditures disadvantages the poorer Indian states whose public investments can not compete with the richer states. The poorer states became unable to provide infrastructure and services necessary to attract investments. Kurian (2001), in an official report of the Indian government, also explains that backward states will not be able to improve their infrastructure and education facilities because their finances are too deteriorated.

To control for the impact of decentralization on inequalities, lagged values of decentralization variables are included in the VECM estimation for India in column 5 of Table 6. Data come from World Bank's Country Database on Fiscal Decentralization. As regards India, data are available from 1980 to 1999. The analysis is not conducted for Brazil because of lack of data over the full period 1985-2003. In column 5, the sub-national share of public expenditures in total public expenditures, which is a proxy of decentralization (net of expenditures in defense and interest), is included. This indicator fell from $72.8 \%$ in 1980 to $67.7 \%$ in 1989. In the nineties, decentralization increased, up to $73.2 \%$ in 1999. This time series is I(1) and is included after being stationarized. The coefficient on the decentralization variable lagged at two periods is positive $(+1.47)$ and significant, which indicates that more decentralization of expenditures means more regional inequalities in India. This result is similar to Rodriguez-Pose and Gill's (2003) findings. Besides, trade openness has still a significant impact on regional inequality, after including the decentalization variable.

\subsubsection{The role of composition of trade in regional inequalities}

In a new economic geography model, Paluzie (2001) shows that opening to manufacturing trade increases regional inequalities. She assumes the immobility of the agricultural sector. Labor force and agricultural inputs are tied to the land and the agricultural population is dispersed throughout the national territory, which encourages firms and industries, in a closed 
economy, to be also dispersed to service the local demand. When the country opens to international trade, local demand can be replaced by foreign demand and, thus, industrial firms leave the agricultural regions to agglomerate and benefit from the advantages of concentration. Besides, an increase in manufacturing exports relatively to agricultural exports will favor the manufacturing region at the expenses of the agricultural regions. Rodríguez-Pose and Gill (2006) provide a similar analysis and argue that changes in trade composition can impact on regional inequality. When agricultural exports decrease relatively to manufacturing exports, regional disparities increase. The idea is that agriculture is tied to the land and is (more and less) equally distributed throuhgout the national territory, whereas manufacturing industry can be subject to agglomerative forces and be concentrated in one region. Agricultural exports are favorable to the whole country, while manufacturing exports are directly favorable only to the industrial center. If manufacturing exports develop at the expense of agricultural exports, trade favors one region and contributes to a rise of regional inequality. Rodríguez-Pose and Gill (2006) find a correlation between the composition of trade and regional inequalities for eight countries (India, Germany...) but they examine correlation, without controlling for other factors of regional disparity.

India and Brazil do not export the same products and the composition of their exports has been following a different evolution since the eighties. Data from World Trade Organization's database allows to build the ratio of manufacturing to agricultural exports for both countries. Unlike Brazil, India exports more and more manufacturing products relatively to agricultural products. The ratios of manufacturing to agricultural exports are reported in Table 4. India's ratio increased from 1.77 in 1980 to 3.57 in 1990 and up to 6.04 in 2003. In Brazil, this ratio changed barely since it was equal to 1.10 in 1985, 1.56 in 1995 and to 1.53 in 2003. Indeed many agricultural products (coffee, sugar, orange juice) are exported from Brazil. In consequence, one can expect exports to aggravate regional inequality in the case of India but not in the case of Brazil.

TAB. 4 - Ratio of manufacturing to agricultural exports for India and Brazil. Selected years over the period 1980-2004.

\begin{tabular}{l|llllll}
\hline & 1980 & 1985 & 1990 & 1995 & 2000 & 2003 \\
\hline $\begin{array}{l}\text { India } \\
\text { Brazil }\end{array}$ & 1.77 & 2.06 & 3.57 & 3.42 & 5.28 & 6.04 \\
& & 1.10 & 1.65 & 1.56 & 2.05 & 1.53 \\
\hline
\end{tabular}

The index of the manufacturing to agricultural export ratio is now included in the VECM for both countries in Table 7 in the Appendix. The higher the ratio, the more important are manufacturing exports relatively to agricultural exports. In column 1 of Table 7 , the ratio is included 
for India. The ratio is a TS serie and is included stationarized. The coefficient on the lagged value of the ratio is significant and positive, equal to +0.03 : an increase in manufacturing exports relatively to agricultural exports increase inequality among Indian states. This result is confirmed in column 2 when the manufacturing exports in percentage of GDP is included. Indeed, in India, industries are mainly located in developed states of South India (Maharashtra and Karnataka). In the nineties, manufacturing exports increased greatly relatively to agricultural exports, thereby favoring the manufacturing area at the expense of the agricultural states. For Brazil, the ratio that is a stationnary serie is included in column 3 of Table 7. The coefficients are negative (equal to -.02) and, as expected, not significant. Last but not least, if the rich nations accept in the future to open up their markets for agricultural goods, it could foster the economic growth of the poor agricultural regions in India. But if the European nations accept such an opening, it could be at the expense of agricultural regions and could exacerbate regional inequalities within their own territory between agricultural and industrial regions. It depends how important agriculture is in the economy and how it is distributed over the national territory.

\section{Discussion}

Empirical results show that trade openness aggravates inequality among Indian states. A first explanation is that the increase in manufacturing exports relatively to agricultural exports has reinforced this inequality. But there may be additionnal mechanisms linking trade openness and regional inequality in India. Brazil's trade openness is found to have reduced regional inequality in Brazil. The regression fails to establish a link between composition of exports and regional inequality. Links between Brazil's trade openness and regional disparities have still to be found. This section discusses some hypotheses on how trade openness might impact on regional inequalities in both countries.

\subsection{Why India's trade openness increases inequality among states}

Crozet and Koenig-Soubeyran (2004) build a theoretical model that predicts that trade liberalization can increase regional inequalities depending on the national geography : trade liberalization fosters agglomeration of economic activities in the border region that has the best and lowest-cost access to foreign markets, thereby creating inequalities between this region and the remote regions. The purpose is now to determine whether such a scenario occurred in India atfer the 1991 trade liberalization.

In India, the coastal and southern states have clearly a better access to foreign markets than the landlocked northern states do. The southern states have always had vast seaports and an active coastline and, in the past, South India welcame foreign traders and travellers. Nowadays, industries located in coastal South India can satisfy both the international market and the internal market. This region has big cities (Mumbay for instance) and is very populated. After the 1991 trade liberalization, coastal regions may have been advantaged relative to interior 
regions. Besides, South India has many other intrinsic qualities. The good practice of English, the good quality of sub-national goverments and of local education (Guha, 2007) made this region even more attractive for Indian and foreign firms.

But is there any evidence for an agglomeration process in South India after trade liberalization? Thanks of the Indian Ministry of Statistics that provides data on state domestic product for each year, it is possible to calculate that, in 1990, South India (formed by Maharashtra, Karnataka, Kerala, Tamil Nadu and Andra Pradesh) that represented 32\% of Indian population produced $29 \%$ of the total Indian output. In 2003, the same states represent $30 \%$ of the Indian population and produce $42 \%$ of the total Indian output. Their share in Indian output increased sharply in the nineties during the liberalization process. Jayanth (2007) reports that Indian firms, from Reliance Industries and Tatas, to the Mittals and Mahindras, that located in the past in the northern parts of the country have been moving into New Dehli or into South India since 1991. The forward group of southern states has come to prominence in manufacturing and tradable goods. Labor and capital migrate from poor states to rich ones, from northern states to southern states. FDI also go mainly to most developed states. Okada and Siddharthan (2007) show that Indian industrial clusters have emerged since 1991 and are now concentrated in the three clustered regions : the region of the capital New Dehli, in Mumbai-Pune in the state of Maharashtra, and in Chennai-Bangalore in the states of Karnata and Tamil Nadu. The proposition here is that Indian coastal states have the best access to foreign markets, due to the precise geography of the country, and that an agglomeration process has occurred in South India after trade liberalization, thereby aggravating the inequalities between South India and North India.

Another channel linking international trade and regional inequality in India could be that of economic growth. The most recent studies on trade openness and growth such as Calderon, Loayza and Schmidt-Hebbel (2004) show that the growth effect is almost null for countries with low levels of per capita income and positive for countries with a good level of development. According to this point of view, trade openness might be beneficial to more developed Indian states and detrimental to the other ones, thereby tending to increase regional disparities. In other words, the richer Indian states in South India and the capital Dehli would benefit from India's trade openness because of their good level of development and the lagged regions of North India would not.

India's insertion into the global economy is certainly linked to increasing regional disparities. Currently, the Indian Central government recognises regional inequalities as a threat to national unity. The problem of rising regional disparities is all the more dangerous since India has a very high cultural and linguistic heterogeneity. Many Indian states have their own language, culture and traditions. Besides, 10 Indian states have large populations (between 50 millions and 170 millions). With such large populations, they could become sovereign countries among the largest ones in the world. There are growing demands for autonomy voiced by southern non-Hindi states. In a context of federalism and linguistic heterogeneity, large regional disparities can become a threat to India's territorial integrity. Political conflicts between forward Indian states 
and the center have emerged strongly since the Eleventh Finance Commission in 2000. Kurian (2001) reports that the richest Indian states were clearly against more transfers and against an increased tax revenue devolution in favor of poorest States. Some southern non-Hindi states no longer want to subsidise the Hindi-states of the North. In consequence, the richest states demand for more fiscal autonomy while the populous backward states (Uttar Pradesh for instance) which cannot be ignored politically by the center demand for more redistributive transfers. In such a context, regional inequalities could lead in India to more fiscal decentralization (if the Southern states win) or more fiscal centralization (if the poorest states take the political advantage). In India, the political disintegration threat could stem primarily from conflict between the centre and a few rich states that seek greater fiscal autonomy.

\subsection{Why Brazil's trade openness reduces inequalities across Brazi- lian states}

A possible explanation, inspired from Krugman and Livas Elizondo's (1996) model, would be that Brazil's trade openness fostered the dispersion of economic activities from São Paulo to the peripheral regions. Krugman and Livas Elizondo's (1996) model shows that trade liberalization may reduce spatial disparities. In the model, repellent forces are congestion costs, pollution, insecurity and high land costs. These forces encourage firms to move to the peripheral region. The agglomeration force is the proximity to large consumer markets, to workers and input suppliers. In autarky, workers follow firms and the centripetal forces are self-reinforcing, ensuring big agglomerations. When the country opens to international trade, consumers and input suppliers are partly replaced by exports and imports respectively and the attraction of the economic center is weakening. Then, there is a dispersal of manufacturing firms throughout the national territory because of the congestion forces.

Brazil opened to international trade in the nineties. Is there any evidence for a dispersal of firms over the same period? Regional inequality in Brazil is mainly due to the concentration of the production in one region, the state of São Paulo. This region enjoys a large consumer market, educated labor and an easy access to foreign markets, which is favorable to concentration. Industries are concentrated in the Southeast. But there are congestion costs. São Paulo is one of the most expensive places to live in Brazil. The cost of land, traffic congestion, delays, accidents and environmental problems are important (Jacobi, 2001). There are many local conflicts with polluting industries. Trade unions are also stronger than those of the periphery. The periphery region (Amazonia, Northeast and South) provides a smaller domestic market but has comparative advantages relative to São Paulo : it offers low wages, lower production costs and more space (Tendler, 2000). Moreover, the states of the periphery provide tax exemptions or subsidies in order to attract firms and the coastal northeast region has a closer access to European and North American markets thanks to its international ports and airports and the south of the country has the closest access to Mercosur countries.

Saboia (2001) and Gutberlet (2007) argue that the Brazilian development trend has been towards industrial decentralization since the beginning of the 1990s. The Annual Survey of 
Mining and Manufacturing Industry conducted by Instituto Brasileiro de Geografia e Estatística (IBGE) in 2003 also confirms that there has been a change in Brazilian industrial localization pattern and a reversal of industrial polarization. The region of São Paulo has experienced a downwards trend in terms of industrial production since São Paulo's industrial production accounts for about 53\% of the nation's industrial output in 1990 and only $40 \%$ in 2004 . There has been a rise of new industries and production lines in other regions. Rodrigues (2002) also confirms the trend towards decentralization of investments away from São Paulo and the extension of production towards the south and the north east of the country. Some firms move out of the state of São Paulo into other states. It seems that indeed an industrial dispersion occured in Brazil in conjunction with Brazil's trade liberalization.

\section{Conclusion}

Regional disparities represent a development challenge in many countries. The persistence of large regional disparities may pose a threat to a country's territorial integrity and affect its political unity. Globalization is frequently cited as a factor of rising disparities across regions within a country. The investigation of this paper of a causal link between trade openness and regional inequality is based on two country cases, India and Brazil, and respectively over the period 1980-2003 and the period 1985-2004.

Empirical evidence from time series analysis shows that Brazil's trade openness has contributed to the reduction of income inequality across Brazilian states. An explanation comes from the composition of trade. Brazil exports many agricultural products relatively to manufacturing products, which favorized the agricultural regions that are not the richer in Brazil. Another possible explanation is that Brazil's trade liberalization has been responsible for the reallocation of some industrial activities to the peripheral regions. The empirical results also show that the inflows of foreign direct investments reinforce the territorial disparities in Brazil by being concentrated in richer states. As regards India, the empirical estimations indicate that greater global integration of India in international trade has gone together with rising regional inequality. More precisely, this paper shows that a rise of India's exports, combined with a shift from exports in agriculture to exports in manufacturing products, could partly explain the rise of inequality among Indian states. Besides, the opening of the country to the foreign markets in the nineties may have also generated an agglomeration process in South India that is the border region with the lowest-cost access to foreign markets. Results also indicate that foreign direct investment aggravates regional inequality in India by being concentrated in richer Indian states. This paper shows that the impact of trade openness on regional inequality may depend on the studied country, on the context in which trade liberalization takes place and on the composition of trade. 


\section{References}

AGHION P., BURGESS R. and Redding S. (2004) The unequal effects of liberalization : Theory and evidence from India. Society for Economic Dynamics, Discussion Paper No. 40.

AZZONI C. (2001) Economic growth and regional income inequality in Brazil. The Annals of Regional Science 35, 133-152.

BARUA A. and CHAKRABORTY P. (2006) Does openness affect inequality? A case study of manufacturing sector of India. International Conference, Economic Integration and Economic Development, Beijing, China.

CALDERON C., LOAYZA N. and SCHMIDT-HEBBEL K. (2004) External conditions and growth performance. Central Bank of Chile, Discussion Paper No.292.

CROZET M. and KOENIG-SOUBEYRAN P. (2004) Trade liberalization and the internal geography of countries. in MAYER T. and MUCCHIELLI J. Mucchielli (Eds) Multinational firms' location and economic Geography, Edward Elgar, Cheltenham, pp. 91-109.

ENGLE R.F. and GRANGER C.W. (1987) Co-integration and error-correction : Representation, estimation and testing. Econometrica 55, 251-276.

ENGLE R.F. and YOO B.S. (1987) Forecasting and testing in co-integrated systems. Journal of Econometrics 35, 143-159.

FIESS N. and VERNER D. (2003) Migration and human capital in Brazil during the 1990s. World Bank Policy Research, Discussion Paper No. 3093.

GE Y. (2006) Regional inequality, industry agglomeration and foreign trade : the case of China. World Institute for Development Economics Research, Discussion Paper No.105.

GONZALES RIVAS M. (2007) The effect of trade openness on regional inequality in Mexico. The Annals of Regional Science 41, 545-561.

GRANGER C.W. (1988) Some recent developments in a concept of causality. Journal of Econometrics 39, 199-211.

GUHA R. (2007) The better half. Outlook India Magazine, Jul 162007.

GUTBERLET J. (2007) The impact of industrial development in Brazil, in Regional Sustainable Development Review : Brazil, [Ed. Luis Enrique Sanchez], in Encyclopedia of Life Support Systems (EOLSS).

HORRIDGE M. and DE SOUZA J. (2004) Economic integration, poverty and regional inequality in Brazil. Center of Policy Studies, Discussion Paper No. 149.

JACOBI P. (2001) The metropolitan region of São Paulo. University of São Paulo, Discussion Paper No. 157.

JAYANTH V. (2007) Why the south attracts. The Hindu, Aug 15, 2007.

KRUGMAN P. and LIVAS ELIZONDO R. (1996) Trade policy and the Third World metropolis. Journal of Development Economics 49, 137-150. 
KURIAN N.J. (2001) Regional disparities in India. New Delhi, Planning Commission of India. HANSEN H. and RAND J. (2006) On the causal links between FDI and growth in developing countries. The World Economy 29, 21-41.

HENDERSON J.V. (1996) Ways to think about urban concentration : neoclassical. Urban systems versus the new economic geography. International Regional Science Review 19, 31-36. LUCAS R.E. (2000) Some macroeconomics for the 21st Centrury. Journal of Economic Perspectives 14, 159-168.

MILANOVIC B. (2005) Half a world : regional inequality in five great federations. World Bank Policy Research, Working Paper No.3699.

NUNNENKAMP P. and STRACKE R. (2007) Foreign direct investment in post-reform India : likely to work wonders for regional development? Kiel Institute of World EConomics, Discussion Paper No. 1375.

OKADA A. and SIDDHARTHAN N.S. (2007) Industrial clusters in India : Evidence from automobile clusters in Chennai and the national capital region. Institute of developing economies, Discussion Paper No. 103.

PALUZIE E. (2001) Trade policy and regional inequalities. Papers in Regional Science 80, $67-85$.

PALUZIE E., PONS J. and TIRADO D.A. (2004) The geographical concentration of industry across Spanish regions, 1856-1995. Review of Regional Research 24, 143-160.

RODRIGUEZ-POSE A. and GILL N. (2003) Is there a global link between regional disparities and devolution? Research Papers in Environmental and Spatial Analysis No. 79.

RODRIGUEZ-POSE A. and GILL N. (2006) How does trade affect regional inequalities? World Development 34, 1201-1222.

SABOIA J. (2001) Industrial decentralization in Brazil in the 1990's : A dynamic regionally distinct process. Nova Economia 11, 85-122.

SACHS J., BAJPAI N. and RAMIAH A. (2002) Understanding regional economic growth in India. Center for International Development, Discussion Paper No.088.

SCHWERT G. W. (1989) Tests for unit roots : a Monte Carlo investigation. Journal of Business and Economic Statistics 7, 147-59.

WEI S. and WU Y. (2001) Globalization and inequality : Evidence from within China. NBER Working Paper No. 8611.

WILLIAMSON J. (1965) Regional inequality and the process of national development. Economic Development and Cultural Change 14, 3-45. 


\section{Appendix A. Data sources}

India

The Republic of India is a federal country consisting of 28 states and seven union territories. The Gini coefficients are calculated from 19 states that are the largest states comprising 98.2 percent of total Indian population in 2003. To calculate the Gini indicator, one needs GDP per capita data at current prices (in local currency) and population data for each Indian state and each year. These data come from the Indian Ministry of Statistics and Programme Implementation. To my knowledge, GDP per capita data by Indian state are available only from the year 1980, which explains that this paper studies the evolution of regional inequalities only from this year. The data for the year 2006 are not available. Data for 2005 exist but data are not reported for a few states, which explains that the studied period ends in 2004. India's exports and imports, the net inflows of foreign direct investment (FDI) in India and India's GDP per capita come from the World Bank's World Development Indicator.

\section{Brazil}

Brazil is a federal country divided in 27 states. GDP per capita and population data for each Brazilian state and each year are provided by the Brazilian institute IBGE (Instituto Brasileiro de Geografia e Estatistica). IBGE provides annual data for the period 1985-2004. Data for 2005 and 2006 are not available. To my knowledge, GDP per capita and population data by Brazilian state and for each year are available only from 1985 to 2004, which has limited the studied period by this paper. Brazil's exports and imports, the net inflows of foreign direct investment (FDI) in Brazil and Brazil's GDP per capita come from the World Bank's WDI.

\section{Appendix B. Econometric methodology}

All time series of Eq. (2) have to be tested for a unit root. The Augmented Dickey-Fuller (ADF) and Phillips-Perron (PP) unit root tests are used. A crucial issue regarding the implementation of the ADF test is the selection of the number $k$ of lagged first-difference terms in the ADF estimated equation. ADF tests are estimated from 5 to 0 lags and the number of lags is then chosen by minimising the Akaike information criterion (AIC). The sequential strategy of the ADF test is also followed. The ADF test equation is first estimated with a time trend and a constant. If the time trend is significant, we stop here. If the time trend is not significant, the ADF equation is estimated with a constant and without a time trend. If the constant is significant, we stop here. If the constant is not significant, the equation of the ADF test is estimated without a time trend and without a constant. An alternative unit root test is the Phillips-Perron test that is also used here to provide robust results on time series' order of integration. The implementation of the Philipps-Perron (PP) test also depends on number of lags. This number is chosen on the basis of the formula reported in Schwert (1989) who suggests $l=T^{1 / 4}$ where $\mathrm{T}$ is the sample size. The paramater is here equal to 2 in view of the used data. 
After testing the series for stationarity, cointegration must be tested between variables integrated of same order $\mathrm{I}(\mathrm{k})$. A $\mathrm{I}(1)$ variable is a non-stationary DS serie that is stationary in first-difference. The Engle-Granger approach is used here to determine the existence of a cointegration relationship. It involves the estimation of the cointegration relationship by OLS. Then, if the residual predicted from this regression is stationary according to an ADF test and the Engle and Yoo (1987) tables, the variables are said to be cointegrated. If two or more variables are found to be cointegrated, error correction models will be estimated. If no variables are cointegrated, Eq.(2) can be estimated with the OLS estimator, after stationarizing the non-stationary variables.

After estimating the error correction models (ECM), I perform in section 4.2 vector error correction models (VECM) to provide robustness checks on the results between trade openness and regional inequality. Granger-causality test is a method for determining whether one time series is useful in forecasting another. A time series $\mathrm{X}$ is said to Granger-cause $\mathrm{Y}$ if lagged values of $\mathrm{X}$ provide significant information about future values of $\mathrm{Y}$. A vector autoregression (VAR) is used to determine whether lagged values of trade openness are useful in forecasting the evolution of regional inequality in Brazil and in India. The VAR is also useful to test for the direction of causality and to check that there is one-way causality from trade openness to regional inequality. A vector error correction model is a VAR with cointegrated variables, including the error-correction mechanism term. The variables must be stationary in the VAR. In consequence, the DS I(1) variables are included in first difference and the TS variables are included stationarized. The optimal lag lenght for autoregressive terms is determined by minimizing the AIC. Owing to the small number of observations (around 20) for each country, the VECM are estimated with the lag lenght of 1 and 2 and find that, across all specifications, the AIC statistics choose the model with a lag lenght of 2 .

\section{Appendix C. Empirical estimations and descriptive data}


FIG. 2 - Regional inequality in India. Per capita income of Indian states in 2001. Source : map of the author. Per capita income is in PPP current dollars.

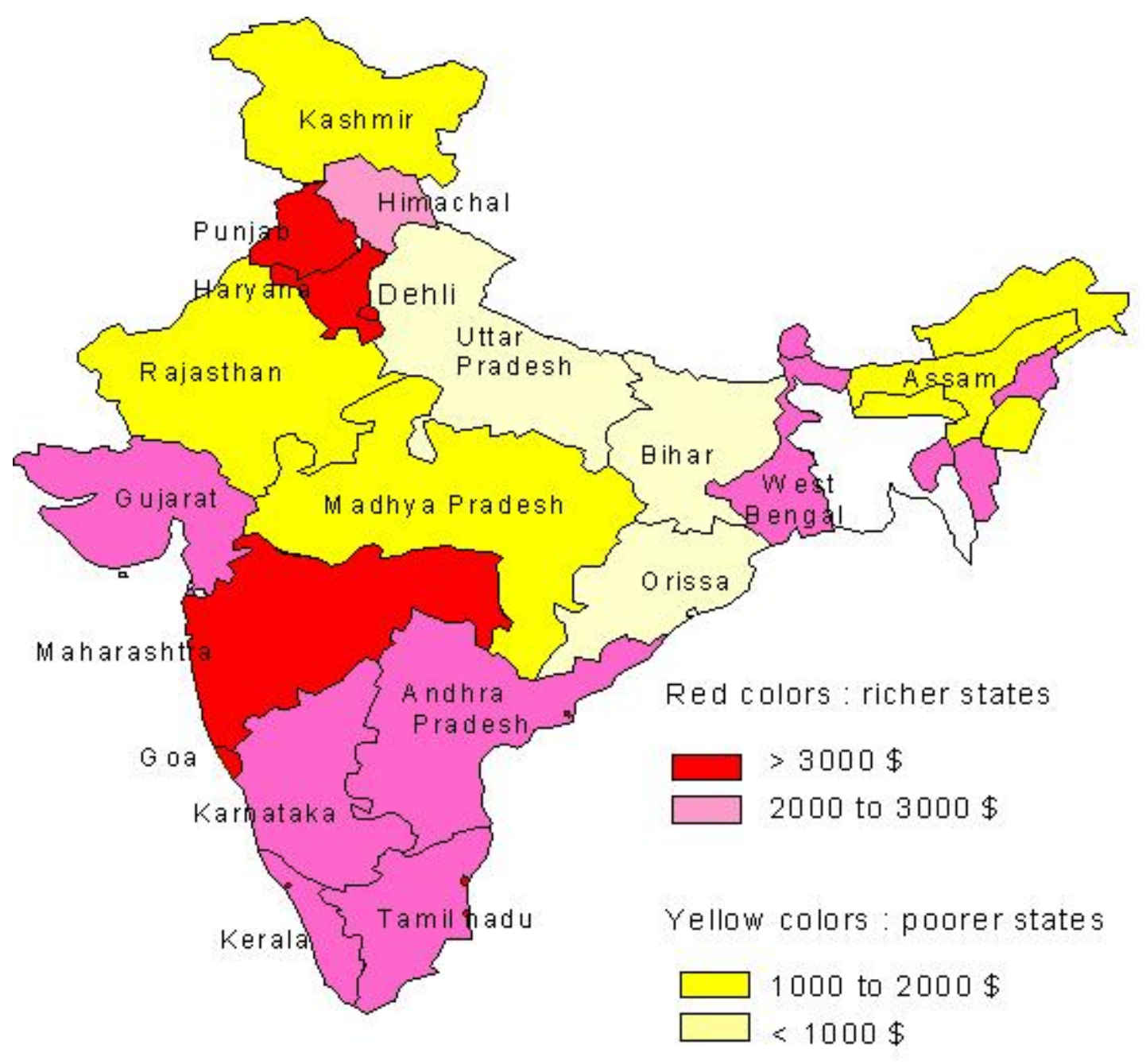


FIG. 3 - Regional inequality in Brazil. Per capita income of Brazilian states in 2001. Source : map of the author. Per capita income is in PPP current dollars.

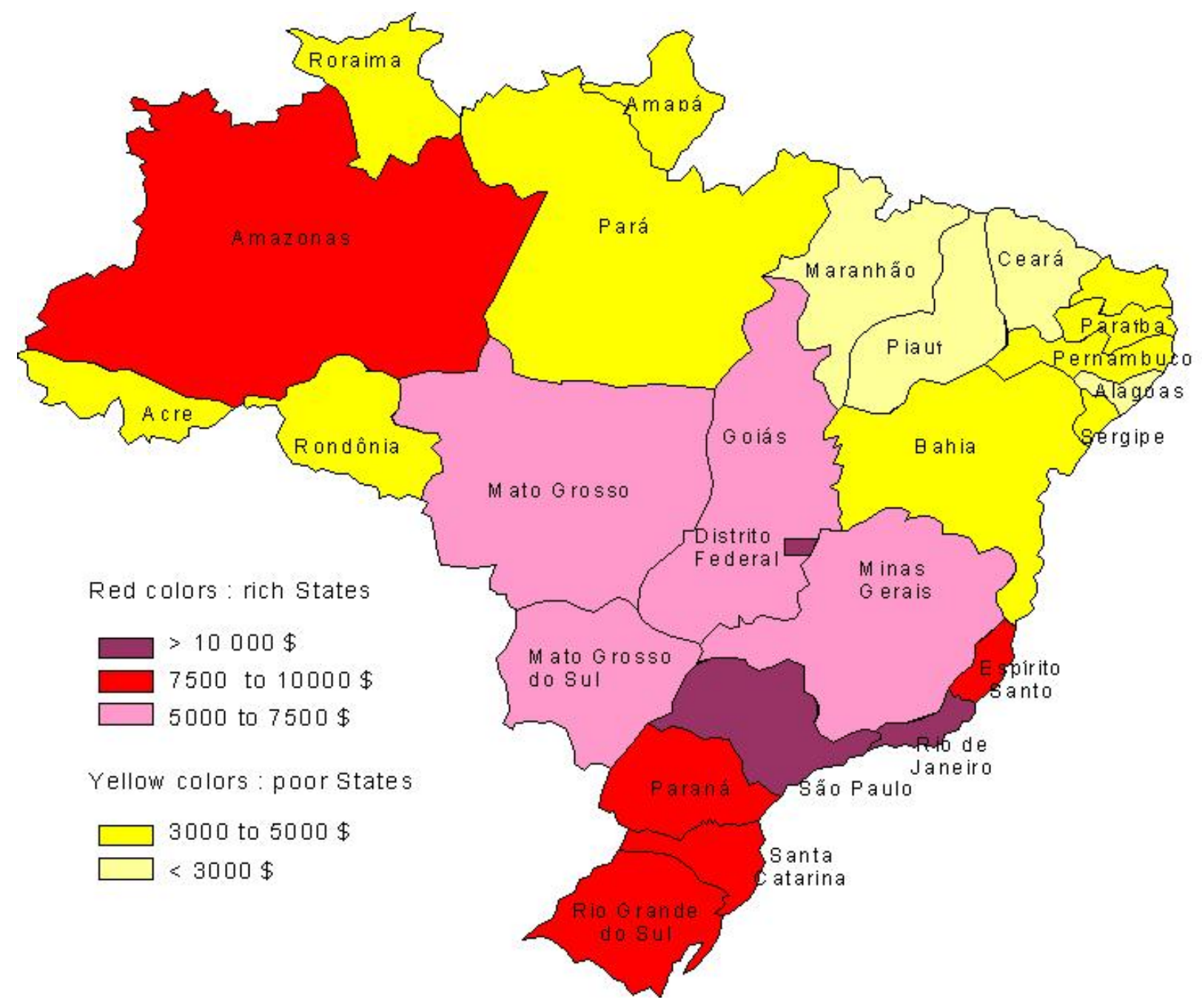


TAB. 5 - India : Per capita state domestic product at local current currency, rupees

\begin{tabular}{|c|c|c|c|c|}
\hline State & $\begin{array}{c}\text { GDP per capita } \\
\text { in } 1980\end{array}$ & $\begin{array}{c}\text { GDP per capita } \\
\text { in } 2003\end{array}$ & $\begin{array}{c}\text { rank } \\
\text { in } 1980\end{array}$ & $\begin{array}{c}\text { rank } \\
\text { in } 2003\end{array}$ \\
\hline Bihar & 917 & 5606 & 1 & 1 \\
\hline Rajasthan & 1222 & 12641 & 2 & 6 \\
\hline Uttar Pradesh & 1278 & 9963 & 3 & 2 \\
\hline Assam & 1284 & 12247 & 4 & 5 \\
\hline Mizoram & 1289 & 22207 & 5 & 18 \\
\hline Tripura & 1307 & 18550 & 6 & 12 \\
\hline Orissa & 1314 & 10164 & 7 & 3 \\
\hline Madhya Pradesh & 1358 & 11500 & 8 & 4 \\
\hline Nagaland & 1361 & 20746 & 9 & 16 \\
\hline Meghalaya & 1361 & 16800 & 10 & 9 \\
\hline Andhra Pradesh & 1380 & 19087 & 11 & 13 \\
\hline Manipur & 1419 & 12878 & 12 & 7 \\
\hline Tamil Nadu & 1498 & 21740 & 13 & 17 \\
\hline Kerala & 1508 & 22776 & 14 & 20 \\
\hline Karnataka & 1520 & 19576 & 15 & 14 \\
\hline Arunachal Pradesh & 1571 & 16916 & 16 & 10 \\
\hline Sikkim & 1571 & 20013 & 17 & 15 \\
\hline Himachal Pradesh & 1704 & 22902 & 18 & 21 \\
\hline West Bengal & 1773 & 18494 & 19 & 11 \\
\hline J\&K (Kashmir) & 1776 & 14507 & 20 & 8 \\
\hline Gujarat & 1940 & 22624 & 21 & 19 \\
\hline Haryana & 2370 & 26818 & 22 & 23 \\
\hline Maharashtra & 2435 & 26858 & 23 & 24 \\
\hline A\& Nicobar islands & 2613 & 28340 & 24 & 25 \\
\hline Punjab & 2674 & 26395 & 25 & 22 \\
\hline Pondicherry & 2794 & 45431 & 26 & 26 \\
\hline Goa & 3145 & 60787 & 27 & 28 \\
\hline Dehli & 4030 & 45579 & 28 & 27 \\
\hline
\end{tabular}

Source of the data : Indian Ministry of statistics. In this table, Bihar is the poorest Indian state in 1980 (rank 1 in 1980) with a per capita GDP equal to 917. Bihar is still the poorest state in 2003 (rank 1). 
TAB. 6 - Links between regional inequality and trade openness. Estimation of the vector error correction models (VECM). Brazil, period 1985-2004 and India, period 1980-2003.

\begin{tabular}{|c|c|c|c|c|c|}
\hline & \multicolumn{2}{|c|}{ Brazil } & \multicolumn{3}{|c|}{ India } \\
\hline & \multicolumn{5}{|c|}{ Dependent variable : } \\
\hline & $\begin{array}{l}\text { regional } \\
\text { inequality } \\
\text { D.lnGinit } \\
\quad(1)\end{array}$ & $\begin{array}{c}\text { trade } \\
\text { openness } \\
\text { D.lnOpenness } \\
(2)\end{array}$ & $\begin{array}{l}\text { regional } \\
\text { inequality } \\
\text { D.lnGinit } \\
\quad(3)\end{array}$ & $\begin{array}{c}\text { trade } \\
\text { openness } \\
\text { D.lnOpenness } \text { Op }_{t} \\
(4)\end{array}$ & $\begin{array}{l}\text { regional } \\
\text { inequality } \\
D . \ln G i n i_{t} \\
\quad(5)\end{array}$ \\
\hline residual $_{t-1}$ & $\begin{array}{l}.34 \\
(.287)\end{array}$ & $\begin{array}{l}-.66 \\
(.817)\end{array}$ & $\begin{array}{l}.57 \\
(.333)^{*}\end{array}$ & $\begin{array}{l}-.48 \\
(.300)\end{array}$ & $\begin{array}{l}-.18 \\
(.392)\end{array}$ \\
\hline D.lnGini $i_{t-1}$ & $\begin{array}{l}-.71 \\
(.224)^{* * *}\end{array}$ & $\begin{array}{l}.20 \\
(1.774)\end{array}$ & $\begin{array}{l}-1.07 \\
(.528)^{* *}\end{array}$ & $\begin{array}{l}-.77 \\
(.723)\end{array}$ & $\begin{array}{l}-.88 \\
(.437)^{* *}\end{array}$ \\
\hline$D . \ln G i n i_{t-2}$ & $\begin{array}{l}-.28 \\
(.136)^{* *}\end{array}$ & $\begin{array}{l}-1.89 \\
(1.242)\end{array}$ & $\begin{array}{l}-.35 \\
(.265)\end{array}$ & $\begin{array}{l}-.54 \\
(.454)\end{array}$ & $\begin{array}{l}-.51 \\
(.200)^{* *}\end{array}$ \\
\hline D.lnOpenness $s_{t-1}$ & $\begin{array}{l}-.16 \\
(.046)^{* * *}\end{array}$ & $\begin{array}{l}-.05 \\
(.825)\end{array}$ & $\begin{array}{c}.49 \\
(.269)^{*}\end{array}$ & $\begin{array}{l}.51 \\
(.377)\end{array}$ & $\begin{array}{c}.33 \\
(.241)\end{array}$ \\
\hline D.lnOpenness $s_{t-2}$ & $\begin{array}{l}-.15 \\
(.039)^{* * *}\end{array}$ & $\begin{array}{l}.26 \\
(.634)\end{array}$ & $\begin{array}{c}.33 \\
(.172)^{*}\end{array}$ & $\begin{array}{l}.57 \\
(.216)^{* * *}\end{array}$ & $\begin{array}{l}.42 \\
(.166)^{* * *}\end{array}$ \\
\hline D.lnGDPcapita ${ }_{t-1}$ & $\begin{array}{l}.44 \\
(.177)^{* *}\end{array}$ & $\begin{array}{l}-2.37 \\
(1.367)^{*}\end{array}$ & $\begin{array}{l}-1.05 \\
(.700)\end{array}$ & $\begin{array}{l}-.48 \\
(.724)\end{array}$ & $\begin{array}{l}-.80 \\
(.704)\end{array}$ \\
\hline D.lnGDPcapita ${ }_{t-2}$ & $\begin{array}{l}-.51 \\
(.171)^{* * *}\end{array}$ & $\begin{array}{l}-.14 \\
(2.043)\end{array}$ & $\begin{array}{l}-1.30 \\
(.519)^{* *}\end{array}$ & $\begin{array}{l}-1.40 \\
(.646)^{* *}\end{array}$ & $\begin{array}{l}-.92 \\
(.480)^{*}\end{array}$ \\
\hline $\ln F D I_{t-1}$ & $\begin{array}{c}.06 \\
(.011)^{* * *}\end{array}$ & $\begin{array}{l}.02 \\
(.121)\end{array}$ & $\begin{array}{l}.005 \\
(.013)\end{array}$ & $\begin{array}{l}-.02 \\
(.027)\end{array}$ & $\begin{array}{l}.009 \\
(.013)\end{array}$ \\
\hline $\ln F D I_{t-2}$ & $\begin{array}{l}-.04 \\
(.010)^{* * *}\end{array}$ & $\begin{array}{l}.11 \\
(.122)\end{array}$ & $\begin{array}{l}.01 \\
(.009)\end{array}$ & $\begin{array}{l}.01 \\
(.015)\end{array}$ & $\begin{array}{c}.02 \\
(.009)^{*}\end{array}$ \\
\hline $\begin{array}{l}\text { Decentralization }_{t-1} \\
\text { of expenditures }\end{array}$ & & & & & $\begin{array}{l}-.23 \\
(.635)\end{array}$ \\
\hline $\begin{array}{l}\text { Decentralization }_{t-2} \\
\text { of expenditures }\end{array}$ & & & & & $\begin{array}{l}1.47 \\
(.493)^{* * *}\end{array}$ \\
\hline constant & $\begin{array}{l}-.006 \\
(.003)^{*}\end{array}$ & $\begin{array}{l}.04 \\
(.050)\end{array}$ & $\begin{array}{c}.09 \\
(.031)^{* * *}\end{array}$ & $\begin{array}{c}.08 \\
(.039)^{* *}\end{array}$ & $\begin{array}{c}.08 \\
(.031)^{* * *}\end{array}$ \\
\hline $\begin{array}{l}\text { observations } \\
R^{2}\end{array}$ & $\begin{array}{c}17 \\
0.88\end{array}$ & $\begin{array}{c}17 \\
0.55\end{array}$ & $\begin{array}{c}21 \\
0.57\end{array}$ & $\begin{array}{c}21 \\
0.55\end{array}$ & $\begin{array}{c}18 \\
0.83\end{array}$ \\
\hline
\end{tabular}

Note : Robust standard errors in parentheses; ${ }^{* * *},{ }^{* *}$ and $*$ represent respectively statistical significance at the $1 \%, 5 \%$ and $10 \%$ levels. For India, FDI is stationarized in first-difference and for Brazil by removing the trend. 
TAB. 7 - Robustness check. Decomposition of exports as determinant of regional inequality. Estimation of the vector error correction model (VECM) for India, on 1980-2003, and Brazil, on 1985-2004.

\begin{tabular}{|c|c|c|c|c|}
\hline & \multicolumn{4}{|c|}{ Dependent variable : D.lnGini ${ }_{t}$, regional inequality } \\
\hline & \multicolumn{2}{|c|}{ India } & \multicolumn{2}{|c|}{ Brazil } \\
\hline & $(1)$ & $(2)$ & $(3)$ & $(4)$ \\
\hline residual $_{t-1}$ & $\begin{array}{c}.86 \\
(.289)^{* *}\end{array}$ & $\begin{array}{l}.45 \\
(.326)\end{array}$ & $\begin{array}{l}.36 \\
(.376)\end{array}$ & $\begin{array}{l}.33 \\
(.392)\end{array}$ \\
\hline D.lnGini $i_{t-1}$ & $\begin{array}{l}-1.34 \\
(.477)^{* * *}\end{array}$ & $\begin{array}{l}-.85 \\
(.355)^{* *}\end{array}$ & $\begin{array}{l}-.73 \\
(.309)^{* *}\end{array}$ & $\begin{array}{l}-.76 \\
(.318)^{* *}\end{array}$ \\
\hline$D . \ln G i n i_{t-2}$ & $\begin{array}{l}-.45 \\
(.297)\end{array}$ & $\begin{array}{l}-.16 \\
(.211)\end{array}$ & $\begin{array}{l}-.26 \\
(.149)^{*}\end{array}$ & $\begin{array}{l}-.28 \\
(.178)\end{array}$ \\
\hline D.lnOpenness $s_{t-1}$ & $\begin{array}{c}.45 \\
(.203)^{* *}\end{array}$ & $\begin{array}{l}.13 \\
(.174)\end{array}$ & $\begin{array}{l}-.14 \\
(.064)^{* *}\end{array}$ & $\begin{array}{l}-.23 \\
(.100)^{* *}\end{array}$ \\
\hline D.lnOpenness $s_{t-2}$ & $\begin{array}{c}.30 \\
(.174)^{*}\end{array}$ & $\begin{array}{c}.33 \\
(.195)^{*}\end{array}$ & $\begin{array}{l}-.13 \\
(.092)\end{array}$ & $\begin{array}{l}-.18 \\
(.069)^{* * *}\end{array}$ \\
\hline $\ln F D I_{t-1}$ & $\begin{array}{l}.01 \\
(.012)\end{array}$ & $\begin{array}{c}-.003 \\
(.009)\end{array}$ & $\begin{array}{c}.06 \\
(.017)^{* * *}\end{array}$ & $\begin{array}{c}.06 \\
(.011)^{* * *}\end{array}$ \\
\hline $\ln F D I_{t-2}$ & $\begin{array}{l}.01 \\
(.009)\end{array}$ & $\begin{array}{c}.02 \\
(.007)^{* *}\end{array}$ & $\begin{array}{c}-.04 \\
(.012)^{* * *}\end{array}$ & $\begin{array}{c}-.04 \\
(.010)^{* * *}\end{array}$ \\
\hline D.lnGDPcapita ${ }_{t-1}$ & $\begin{array}{l}-1.19 \\
(.550)^{* *}\end{array}$ & $\begin{array}{l}-.87 \\
(.482)^{*}\end{array}$ & $\begin{array}{c}.49 \\
(.131)^{* * *}\end{array}$ & $\begin{array}{c}.43 \\
(.150)^{* * *}\end{array}$ \\
\hline D.lnGDPcapita $t_{t-2}$ & $\begin{array}{l}-1.10 \\
(.441)^{* *}\end{array}$ & $\begin{array}{l}-.87 \\
(.275)^{* * *}\end{array}$ & $\begin{array}{l}-.48 \\
(.229)^{* *}\end{array}$ & $\begin{array}{l}-.44 \\
(.250)^{*}\end{array}$ \\
\hline (manuf exports/ agricultural exports $)_{t-1}$ & $\begin{array}{c}.03 \\
(.017)^{*}\end{array}$ & & $\begin{array}{l}-.02 \\
(.090)\end{array}$ & \\
\hline$(\text { manuf exports/ agricultural exports })_{t-2}$ & $\begin{array}{l}.005 \\
(.017)\end{array}$ & & $\begin{array}{l}-.02 \\
(.053)\end{array}$ & \\
\hline manuf exports in $\%$ of $\mathrm{GDP}_{t-1}$ & & $\begin{array}{l}.25 \\
(.094)^{* * *}\end{array}$ & & $\begin{array}{l}.06 \\
(.056)\end{array}$ \\
\hline manuf exports in $\%$ of $\mathrm{GDP}_{t-2}$ & & $\begin{array}{l}-.02 \\
(.103)\end{array}$ & & $\begin{array}{l}.01 \\
(.057)\end{array}$ \\
\hline constant & $\begin{array}{c}.10 \\
(.028)^{* * *}\end{array}$ & $\begin{array}{c}.07 \\
(.020)^{* * *}\end{array}$ & $\begin{array}{l}.01 \\
(.061)\end{array}$ & $\begin{array}{c}-.006 \\
(.004)\end{array}$ \\
\hline Observations & 21 & 21 & 17 & 17 \\
\hline$R^{2}$ & 0.69 & 0.75 & 0.88 & 0.91 \\
\hline
\end{tabular}

Note : Robust Standard errors in parentheses; ***, ** and * represent respectively statistical significance at the $1 \%, 5 \%$ and $10 \%$ levels. For India, FDI is stationarized in first-difference and for Brazil by removing the trend. 